\title{
Investigations on effectiveness of wheat and rice straw mulches on moisture retention in potato crop (Solanum tuberosum L.)
}

\author{
Lalit Goel $^{1}$ (1) $\cdot$ Vijay Shankar $^{1} \cdot$ R. K. Sharma ${ }^{1}$
}

Received: 24 January 2019 / Accepted: 14 October 2019 / Published online: 25 October 2019

(c) The Author(s) 2019

\begin{abstract}
Purpose Mulching is a practice recommended for soil moisture conservation in potato. The wheat straw and rice straw obtained as major crop residues were used as mulching materials to compare their effectiveness for soil moisture retention in potato crop.

Methods The field experiments were conducted in a randomized complete block design replicated thrice with three treatments viz. plots incorporated with wheat straw mulch, rice straw mulch at the rate of 10 tonnes per hectare each and no mulch serving as control. The soil moisture was determined using a soil moisture probe and data were recorded daily at $10 \mathrm{~cm}$, $20 \mathrm{~cm}$ and $30 \mathrm{~cm}$ soil depths. The Field Emission Scanning Electron Microscopy was used to investigate moisture retention characteristics of the mulch materials.

Results Soil moisture retention varied as wheat straw mulch $>$ rice straw mulch $>$ no mulch at $10 \mathrm{~cm}, 20 \mathrm{~cm}$ and $30 \mathrm{~cm}$ soil depths, respectively. Highest moisture retention in wheat straw mulch at $10 \mathrm{~cm}$ depth is attributed to better moisture absorption ability of wheat straw in comparison to rice straw. Field Emission Scanning Electron Microscope images indicated the presence of smaller sized micro tubes in wheat straw than rice straw, which resulted in more water retention, thereby substantiating the findings of the study.

Conclusion Wheat straw mulch is more effective than rice straw mulch for shallow rooted crops like potato, due to better moisture absorption and retention in upper soil layer.
\end{abstract}

Keywords Elements $\cdot$ FESEM-EDS $\cdot$ Moisture retention $\cdot$ Mulch

\section{Introduction}

Efficient water management is one of the major challenges faced by present day agriculture. For successful agriculture, proper utilization of water is essential which can be achieved by adopting suitable water conservation measures (Shankar et al. 2017). Several techniques like micro irrigation, conservation tillage, organic farming, rotational grazing, and dry farming including mulching are adopted for soil moisture

Lalit Goel

1_goyal74@nith.ac.in

Vijay Shankar

vsdogra12@gmail.com

R. K. Sharma

rksnithp61@gmail.com

1 Civil Engineering Department, National Institute of Technology Hamirpur, Hamirpur, Himachal Pradesh 177005, India conservation. Mulching is the application of any plant residue or other materials for covering top soil surface for soil moisture retention (Chavan et al. 2010). The unique ability of mulches to retain moisture in case of cropped and fallow soils has been observed by several researchers (Havlin et al. 1990; Dalrymple et al. 1993; Rathore et al. 1998; Duiker and Lal 1999; Ji and Unger 2001; Giordani et al. 2004; Chavan et al. 2010). Mulching has been effectively used for conserving soil moisture and increasing productivity in several crops like wheat (Rahman et al. 2005), maize (Zhang et al. 2005), sorghum (Chavan et al. 2010), tomato (Ramalan and Nwokeocha 2000), turmeric (Kumar et al. 2003), Sunflower (Tariq et al. 2001) and sesame (Teame et al. 2017). Various mulch materials have also been recommended in case of potato crop for conserving soil moisture, saving irrigation water and increasing yield (Burger and Nel 1984; Mahmood et al. 2002, Uniyal and Mishra 2003; Kar and Kumar 2007; Dash et al. 2018). 
About 500 million tonnes of the crop residues are generated in India every year (MNRE (Ministry of New and Renewable Energy Resources) 2009). These crop residues are often an agri-waste to the farmers. Singh and Panigrahy (2011) reported that $84 \%$ of agriculture residues burning is from the Rice-Wheat system alone. Thus the residues of both these crops, i.e. rice straw and wheat straw, were selected to be used as mulch for comparing their moisture retaining potential in the potato crop. Potato is a crop that holds an important position in the global economy. The root system of potato is shallow, with weak soil penetration and often unable to penetrate the plough pan of soil (Lesczynski and Tanner 1976; Van Loon 1981; Stalham et al. 2007; Iwama 2008) which makes it inefficient to extract water and minerals from deeper soil layers (Opena and Porter 1999; Dechassa et al. 2003). Therefore, potato crop cannot grow well under a high degree of soil moisture depletion and requires frequent irrigations (Saha et al. 1997; Poddar et al. 2018). Mulching provides the additional advantage of soil moisture conservation and reduces the irrigation requirement of the crop (Saha et al. 1997).

The present study was conducted to investigate the performance of wheat straw mulch and rice straw mulch for their moisture retaining ability in the potato crop. An effort has been made to find the phenomenon responsible for water retention at micro level using FESEM (Field Emission Scanning Electron Microscopy) and EDS (Energy Dispersive Spectroscopy) technique. FESEM was performed to understand the distribution of the structures present in mulched soils, wheat straw mulch and rice straw mulch for explaining the moisture retaining behaviour of the mulches. There are hardly any reports of FESEM studies in mulched soils and mulching materials. Therefore, present study is an attempt to evaluate wheat straw mulch and rice straw mulch for their soil moisture retention capacity and investigate the microstructure of samples of soil and mulch materials to understand their moisture retention behaviour.

\section{Materials and methods}

\section{Study area and experimental site}

Field experiments were performed at agricultural experimental station of National Institute of Technology (NIT) Hamirpur, Himachal Pradesh (India) from January to April 2018. The agricultural field was located at latitude: $31^{\circ} 42^{\prime}$ $40^{\prime \prime} \mathrm{N}$; longitude: $76^{\circ} 31^{\prime} 33^{\prime \prime} \mathrm{E}$; altitude: $900 \mathrm{~m}$ above mean sea level. The region belongs to sub-humid mid hills of western Himalayas with an average annual rainfall of $1572 \mathrm{~mm}$, 80 percent of which falls during the rainy season (June to September) due to south west monsoons. The soil of experimental area was coarse textured sandy loam.

\section{Treatments}

Three treatments used in the study consisted of rice straw mulch (RM), wheat straw mulch (WM) applied at the rate of 10 tonnes per hectare each, and no mulch (NM). The experiment was set up in a randomized complete block design (RCBD) with three replications for each treatment with a plot size of $3 \mathrm{~m} \times 1 \mathrm{~m}$ under each replication. A popular variety of potato "Kufri Jyoti" was used in the study and sowing of the crop was done in January 2018 by standard ridge and furrow method with a spacing of $45 \mathrm{~cm} \times 15 \mathrm{~cm}$. Rate of application of manures and fertilizers used per hectare was 25 tonnes farmyard manure (FYM), $120 \mathrm{~kg} \mathrm{~N}, 80 \mathrm{~kg} \mathrm{P}$ and $60 \mathrm{~kg} \mathrm{~K}$. Full dose of FYM, P and K and half dose of N were applied at the time of sowing and remaining half dose of $\mathrm{N}$ was applied after 30 days of sowing as per package of practices recommended by Himachal Pradesh state agriculture university (CSKHPKV 2008). Mulching was also done after first earthing up and both the mulches were used as whole straw without any chopping or other treatment. Uniform light irrigations to the depth of $50 \mathrm{~mm}$ were applied frequently in all the plots and total eleven irrigations were used during the crop season.

\section{Soil moisture measurement}

A soil moisture probe-Diviner 2000 (Sentek Pty Ltd., Stepney, South Australia) was used to observe the soil moisture. The PVC pipes were installed vertically in the middle of each plot to insert the probe for recording the soil moisture data. The PVC pipes were driven to a depth of $100 \mathrm{~cm}$ and observations were recorded at $10 \mathrm{~cm}$ intervals. Potato is a shallow rooted crop with approximately $85 \%$ of the root length of crop being concentrated in the upper $30 \mathrm{~cm}$ layer of the soil (Opena and Porter 1999). Hence, the soil moisture data up to $30 \mathrm{~cm}$ has been used in the present study.

\section{FESEM-EDS investigations}

FESEM is a powerful and versatile microscopic method capable of magnifying the images up to $150000 \times$ and together with EDS method provides elemental composition map of the sample. FESEM is often used to examine microstructures of soils to assess their environmental and mechanical behaviour (Mitchell 1993). FESEM-EDS based analytical method is used for the automatic assessment and measurement of the geometric and morphological characteristics such as particle size, shape, arrangement and distribution in soils, which are important for understanding the soil behaviour (Liu et al. 2015). Many macroscopic soil properties are frequently explained in terms of micro 
structural behaviour such as distribution and connectivity of pores, particle size, shape and distribution, along with the arrangement of grains and grain contacts (Romero and Simms 2008). The procedure for collection and preparation of samples, subjected to FESEM and EDS investigations is explained below.

\section{Soil samples}

Three soil samples namely no mulched soil (NMS), wheat straw mulched soil (WMS) and rice straw mulched Soil (RMS) were collected from NM, WM and RM plots, respectively. The samples were collected from a depth of $10 \mathrm{~cm}$ after 6 months of application of mulch. The samples were obtained using the method described by Chen et al. (1980). The soil samples were extracted by sampling tubes. Thereafter the sampling tubes with soil samples were submerged in liquid nitrogen to freeze the moisture present in the soil samples. The sampling tubes were then warmed by rubbing the outside to release the frozen samples. These frozen cut soil samples were glued on carbon tape which was mounted on an aluminum stub. Gold sputtering was done on its exposed surface, facing upward for $75 \mathrm{~s}$ before they were subjected to the FESEM-EDS measurement.

\section{Mulch samples}

The method used by Ramamurthy and Kannan (2009) was followed for the preparation of mulch samples for FESEM-EDS. Mulch samples used in the study included Wheat straw (WS) and Rice straw (RS). These mulch samples were washed thoroughly with distilled water to remove the external matter and foreign particles present on sample surface followed by shade drying. Then the moisture from the samples was removed by drying them in an oven at a temperature of $60{ }^{\circ} \mathrm{C}$ for $4 \mathrm{~h}$. The samples were finally cut to 1-2 $\mathrm{mm}$ small pieces before subjecting to FESEM-EDS measurement.

\section{Characterization of sample morphology and elemental composition}

The morphology and micrographs were recorded using an FEI-450 Quanta field emission scanning microscope (Thermo Fisher Scientific, Oregon, USA). The chemical composition of samples was determined using energy dispersive X-ray spectroscopy (EDS) coupled to FESEM. Samples were glued on the sample holder and then gold coated to form a readily conductive surface. The FESEM micrographs and resultant EDS spectrum were recorded for all the samples.

\section{Results and discussion}

\section{Soil moisture}

Soil moisture was recorded with soil moisture probe from 26th February to 20th April, 2018. The moisture data obtained at $10 \mathrm{~cm}, 20 \mathrm{~cm}$ and $30 \mathrm{~cm}$ depths in the crop root zone are depicted in Figs. 1, 2 and 3, respectively. At $10 \mathrm{~cm}$ soil depth, the maximum soil moisture was observed in WM plots, followed by RM and NM plots, showing an average increase of $42 \%$ and $32 \%$ for WM and RM, respectively
Fig. 1 Soil moisture at $10 \mathrm{~cm}$ depth

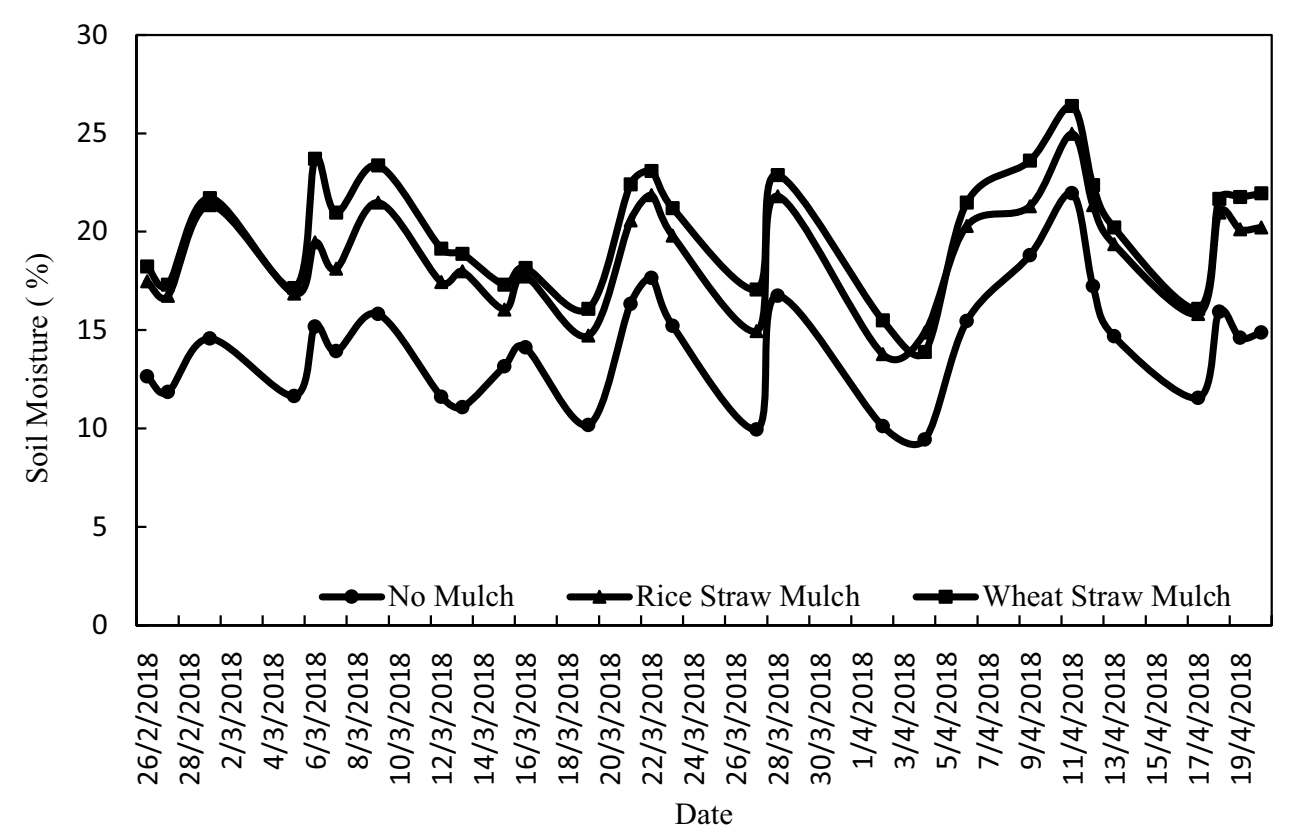


Fig. 2 Soil moisture at $20 \mathrm{~cm}$ depth

Fig. 3 Soil moisture at $30 \mathrm{~cm}$ depth

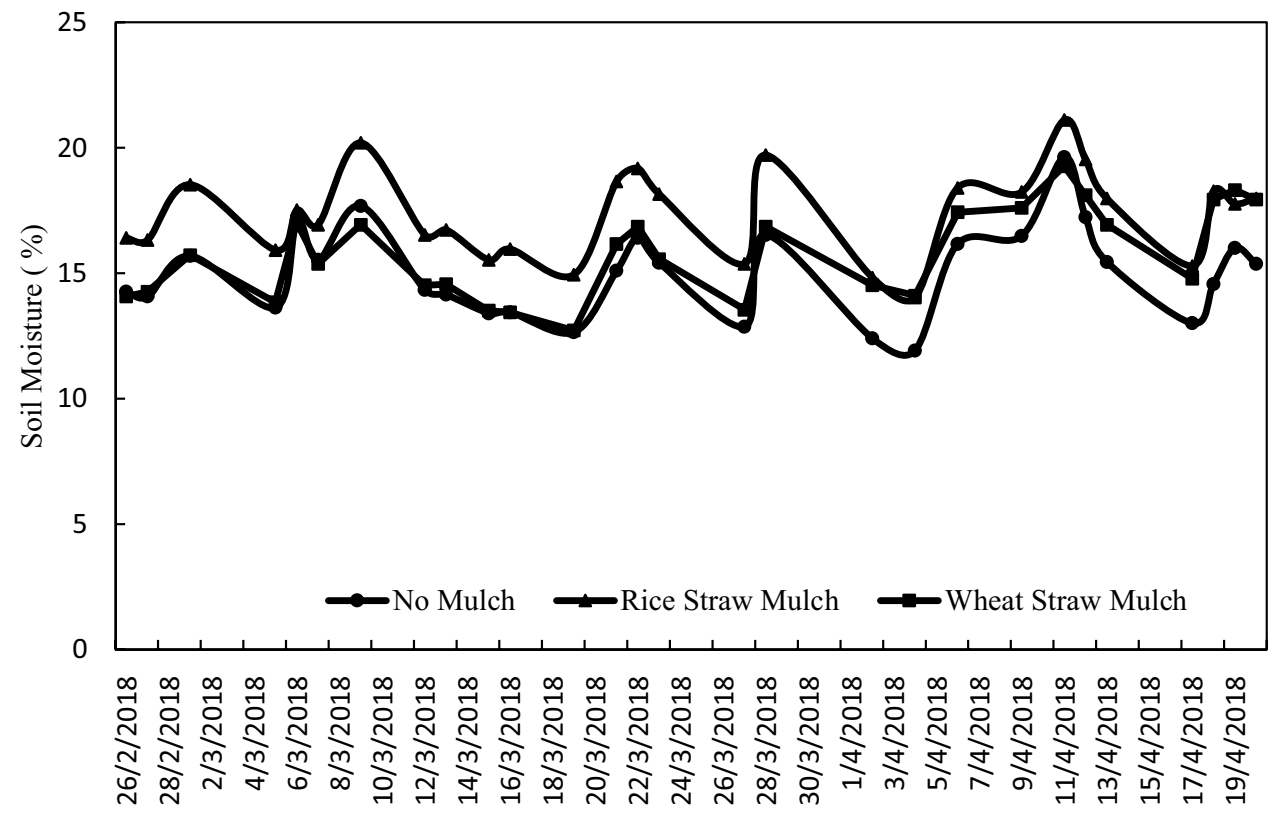

Date

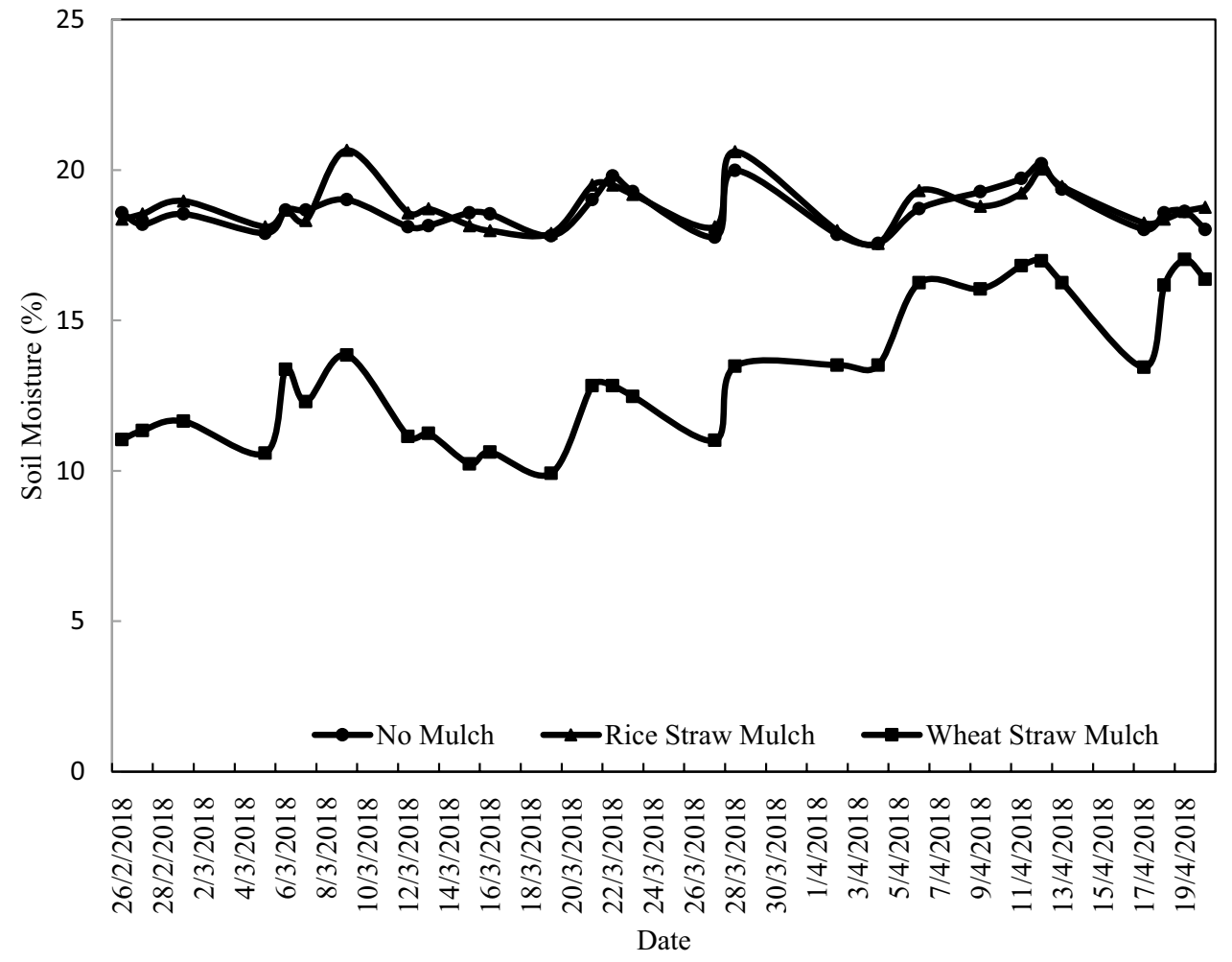

over NM (Fig. 1). At $20 \mathrm{~cm}$ depth, the order of soil moisture retention was $\mathrm{RM}>\mathrm{WM}>\mathrm{NM}$. Though the moisture retention was high in RM and WM in comparison to NM, but the average moisture increase was $15.65 \%$ in RM and $5.12 \%$ in WM (Fig. 2). At $30 \mathrm{~cm}$ depth, the moisture content in RM and NM was at par, but a sudden drop in soil moisture was observed in plots with WM (Fig. 3). It could be inferred from the data at various soil depths that at the applied levels of uniform irrigation the moisture content was high in top layers in mulched plots whereas high soil moisture content was observed in deeper soil layers in plots without mulch. Thus, the study indicated that the applied mulches conserved 
the moisture in the top layer and prevented it from percolating down in the deeper soil layer away from the crop root zone. The highest moisture content with WM in the top $10 \mathrm{~cm}$ layer showed that WM absorbed more water than RM and checked the deep percolation loss more effectively. This was attributed to the mulch characteristics, which were further investigated using FESEM. Since mulches formed a physical barrier, limited the soil water evaporation and prevented percolation losses, the moisture retention in the top soil layers increased. Moisture conserving abilities of mulches reported by Mulumba and Lal (2008) and Xing et al. (2012) found an increase in soil moisture capacity by $18 \%$ to $35 \%$ and $5.7 \%$ to $9.5 \%$, respectively. Results of the present study have shown an increase in soil moisture from $32 \%$ to $42 \%$ at $10 \mathrm{~cm}$ depth and $5.12 \%$ to $15.65 \%$ at $20 \mathrm{~cm}$ soil depth.

\section{Morphological characterization from FESEM studies}

The FESEM studies were conducted to investigate micro level causes of enhanced moisture retention by wheat straw in comparison to rice straw.

\section{FESEM micrographs of soil samples}

FESEM, studies provided high resolution micrographs of samples, owing to the small de Broglie wavelength of electrons. This enabled the samples to be examined in fine details. The morphology of NMS, RMS and WMS soil samples, obtained from the field after 6 months of mulch application was determined by FESEM as shown in Plates 1, 2 and 3, respectively. The images depicted that all the soil samples, i.e. NMS, RMS and WMS were homogenous consisting of small micrometer scale grains having irregular

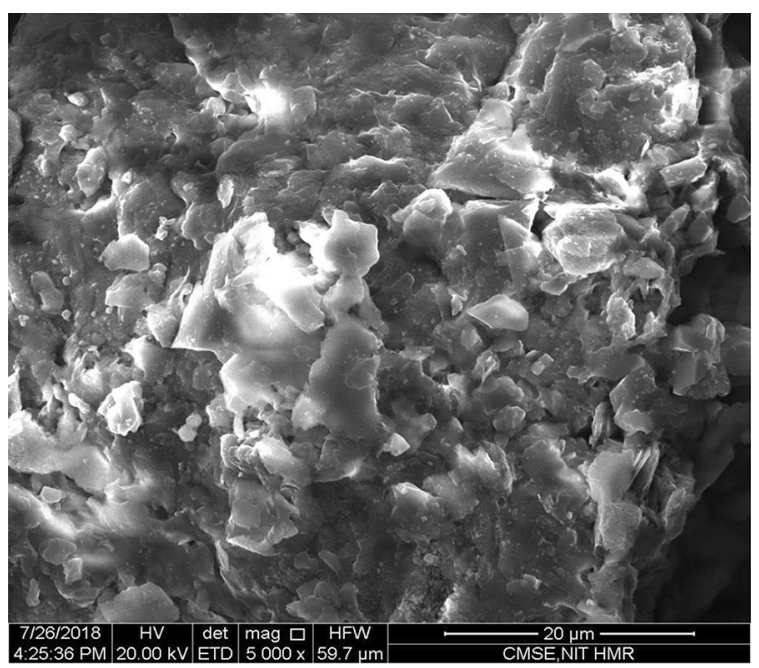

Plate 1 FESEM micrograph of Soil under NM (NMS)

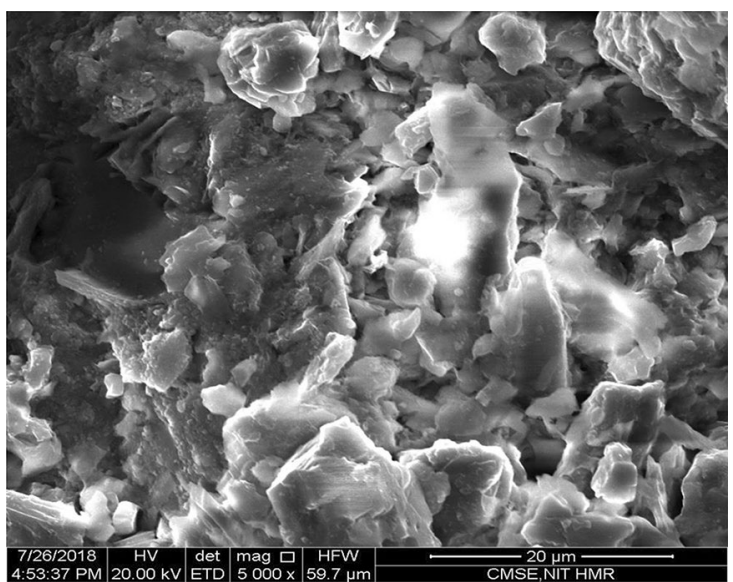

Plate 2 FESEM micrograph of Soil under RM (RMS)

platelet shape. The size of the particles ranged from 1 to $5 \mu \mathrm{m}$. Comparison of the images showed no significant difference in the soil samples. This indicated that mulching did not change the properties and structure of soil over a short period of time. These results are also in agreement with the work of Schonbeck and Evanylo (1998) who reported no significant difference in the physical properties of soil by mulching. Organic mulching has been reported to improve soil surface aggregation within 2 to 8 years (Black 1973).

\section{FESEM micrographs of mulch samples}

FESEM micrographs of rice straw (RS) and wheat straw (WS) are shown in Plates 4 and 5. Micro tubes were observed in both mulch samples. The size of tubes in case of RS was about $20 \mu \mathrm{m}$, whereas it was about $10 \mu \mathrm{m}$ in

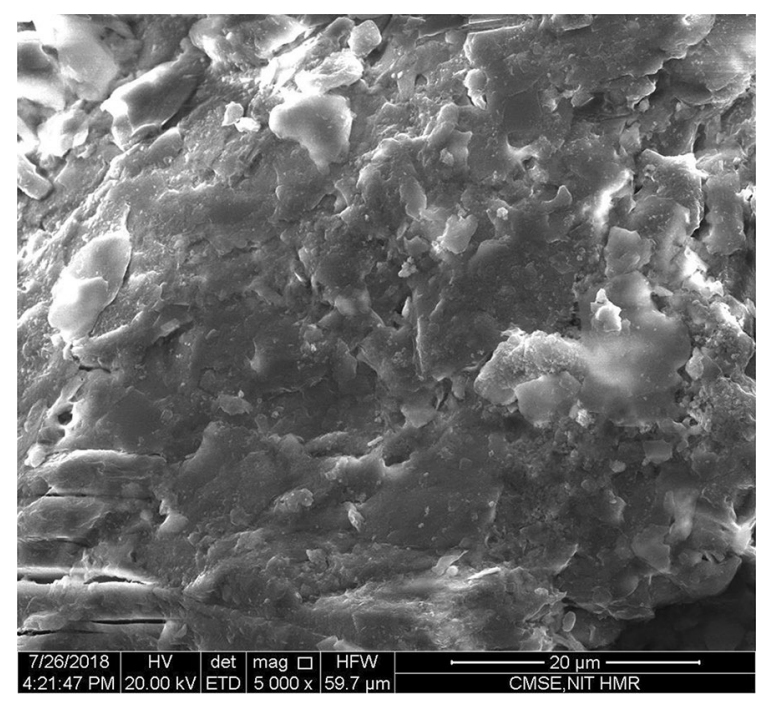

Plate 3 FESEM micrograph of soil under WM (WMS) 


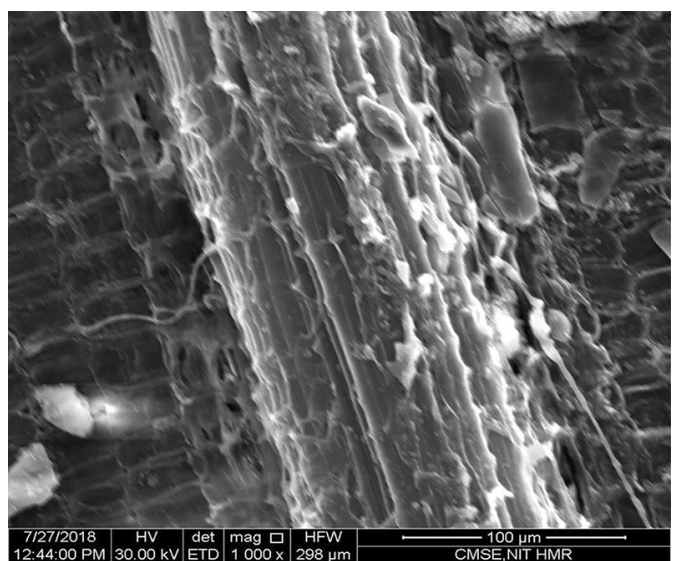

Plate 4 FESEM micrograph of RS

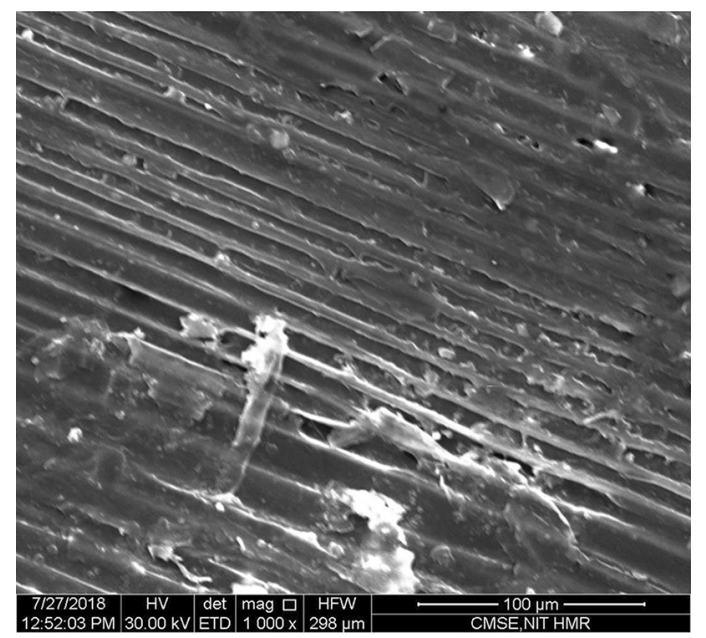

Plate 5 FESEM micrograph of WS

WS. Micrograph of RS showed plasma like layers but that of WS showed the continuous tubular structures. The continuous tubular morphology of WS and smaller diameter of micro tubes in WS seems responsible for retaining more moisture because these micro tubes act as capillaries and hold the water tightly due to surface tension. Narrower the capillary, more is the rise resulting in higher water retention. Thus, the capillary rise in WS was nearly double than that of RS since the diameter of the RS tubes observed was twice the diameter of micro tubes observed in WS. Further, the plasma like layers observed in the micrograph of RS did not allow water molecules to get entrapped into these layers. Analysis of soil moisture data revealed an increase in soil moisture retention to the extent of $42 \%$ in WM and $32 \%$ in RM as compared to NM at $10 \mathrm{~cm}$ soil depth. But the soil moisture drastically reduced at $30 \mathrm{~cm}$ depth in WM plots. This indicated that wheat straw mulch present in the top layer retained maximum moisture and prevented it from percolating to deeper layers. The FESEM images of mulch materials explain the soil moisture retention behaviour in the field. Therefore, WM is capable of holding water in the uppermost soil layer, which is beneficial for shallow rooted crops like potato.

\section{Elemental composition}

The soil and mulch materials are composed of various elements. The chemical composition of the elements present in the soil samples was detected with Energy dispersive spectrometry (EDS).

\section{Elemental composition of soil samples}

The EDS Spectrum of NMS, RMS and WMS detected Oxygen $(\mathrm{O})$, Silicon $(\mathrm{Si})$, Aluminum $(\mathrm{Al})$, Iron $(\mathrm{Fe})$, Magnesium $(\mathrm{Mg})$, Potassium $(\mathrm{K})$ and Nitrogen $(\mathrm{N})$ in all the soil samples. The EDS spectrum of NMS showed presence of $68.5 \% \mathrm{O}, 13.28 \% \mathrm{Si}, 9.1 \% \mathrm{Al}, 4.73 \% \mathrm{Fe}, 2.63 \% \mathrm{Mg}, 1.02 \%$ $\mathrm{K}$ and $0.75 \% \mathrm{~N}$ (Fig. 4). The atomic percentages of the elements observed in RMS were $69.28 \% \mathrm{O}, 13.62 \% \mathrm{Si}, 9.97 \%$ $\mathrm{Al}, 2.22 \% \mathrm{Fe}, 0.91 \% \mathrm{Mg}, 1.27 \% \mathrm{~K}, 1.99 \% \mathrm{~N}$ and $0.74 \% \mathrm{Na}$ (Fig. 5). The EDS analysis of WMS detected $65.65 \%$ O, $19.83 \% \mathrm{Si}, 8.46 \% \mathrm{Al}, 3.12 \% \mathrm{Fe}, 1.16 \% \mathrm{Mg}, 0.81 \% \mathrm{~K}$ and $0.98 \% \mathrm{~N}$ (Fig. 6). The increase in elemental nitrogen over control was observed in both RM and WM. This may be due to high moisture content under mulch which increased the mineralization of soil nitrogen. Bhagat et al. (2016) also reported that there was an increase in nitrification potential of the soil after application of mulch and high dose of nitrogen fertilizer due to the $\mathrm{N}$-mineralization process, which increased the supply of $\mathrm{NH}_{4}{ }^{+}$ions. Similar practice i.e. application of mulch along with the recommended dose of fertilizers used in the present study is attributed to the increased nitrogen content in mulched samples.

\section{Elemental composition of mulch samples}

The EDS Energy Spectrum of RS and WS are shown in Figs. 7 and 8, respectively. The prominent elements detected in mulch samples though EDS were Carbon(C), Oxygen (O) and Silicon (Si) which were $55.26 \%, 40.93 \%$ and $3.81 \%$, respectively in RS with corresponding values of $58.69 \%$, $40.84 \%$ and $0.47 \%$, respectively in WS. C and O in both the mulch samples were almost comparable, but $\mathrm{Si}$ was found to be more in RS than WS. This is because rice straw is actually rich in silicates due to which it is not considered good as fodder for cattle. Though, both the mulch samples possessed a high Carbon content, $\mathrm{C}$ was not detected in soil samples, since the release of $\mathrm{C}$ takes place after the decomposition of mulch which is a time-consuming process. Change in 


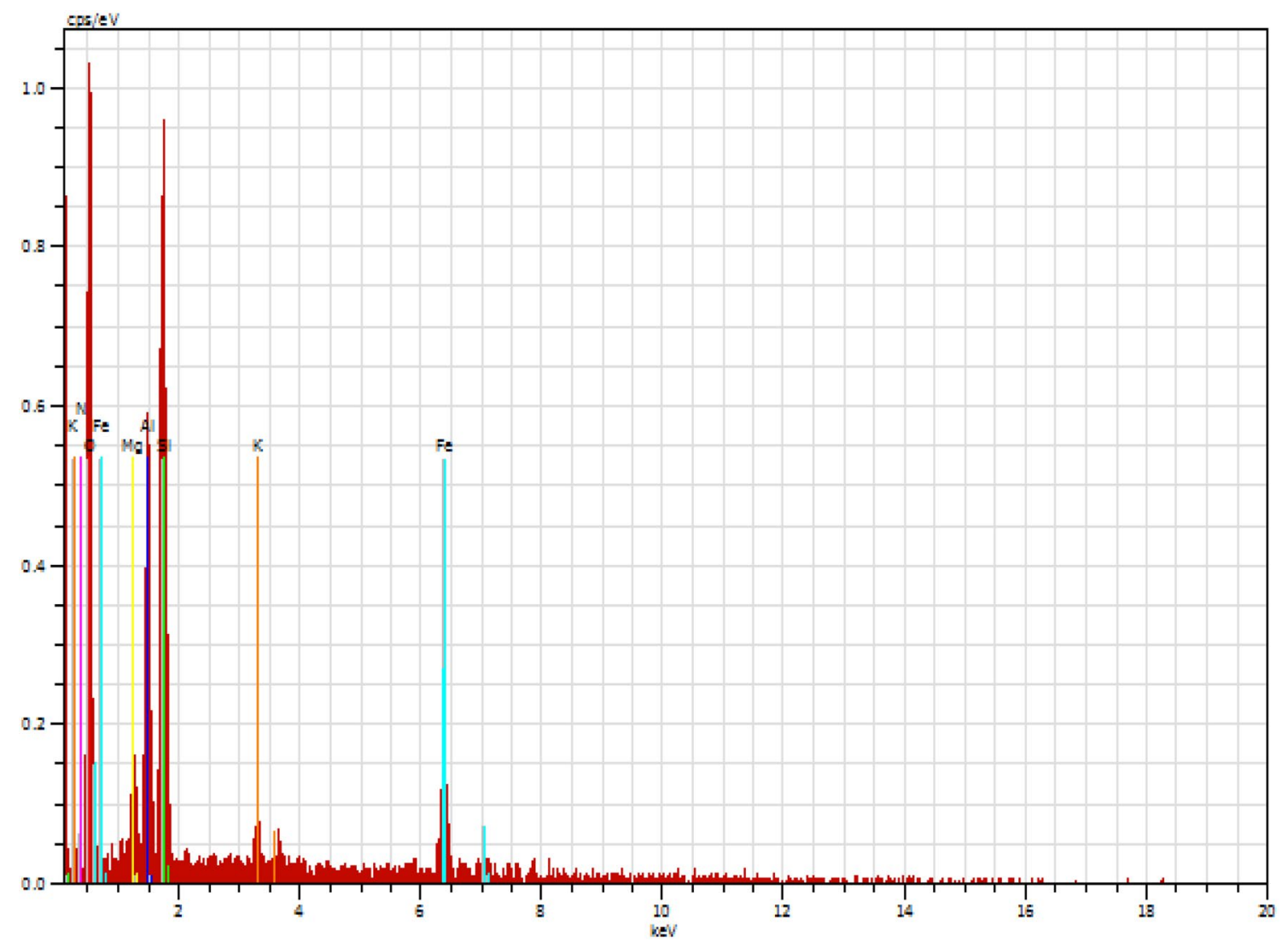

Fig. 4 EDS spectrum of NMS

soil's total organic matter occurs slowly after mulching (Powlson and Jenkinson 1981; Schnurer et al. 1985; Persson and Kirchmann 1994). Findings of present study are in line with that of Shashidhar et al. (2008) which could not find any measurable increase in organic carbon content with rice straw.

\section{Conclusion}

The present study was focused to investigate the use of wheat straw mulch and rice straw mulch for their moisture retaining ability in potato crop at soil depths of $10 \mathrm{~cm}$, $20 \mathrm{~cm}$ and $30 \mathrm{~cm}$. The analysis of observed soil moisture data revealed that enhanced soil moisture retention in wheat straw mulch and rice straw mulch was $42 \%$ and $32 \%$, respectively at $10 \mathrm{~cm}$ soil depth; whereas corresponding increase at $20 \mathrm{~cm}$ soil depth was $5.12 \%$ and $15.65 \%$. The experimental findings were substantiated by the results obtained from FESEM-EDS studies, wherein small micro tubes with an approximate size of $10 \mu \mathrm{m}$ in wheat straw and $20 \mu \mathrm{m}$ in rice straw were observed. Narrower capillaries in wheat straw were responsible for higher water retention as compared to rice straw. Wheat straw mulch also prevented moisture percolation to deeper soil layers. In shallow rooted crops like potato, wheat straw mulch provides effective soil moisture retention in the root zone. 


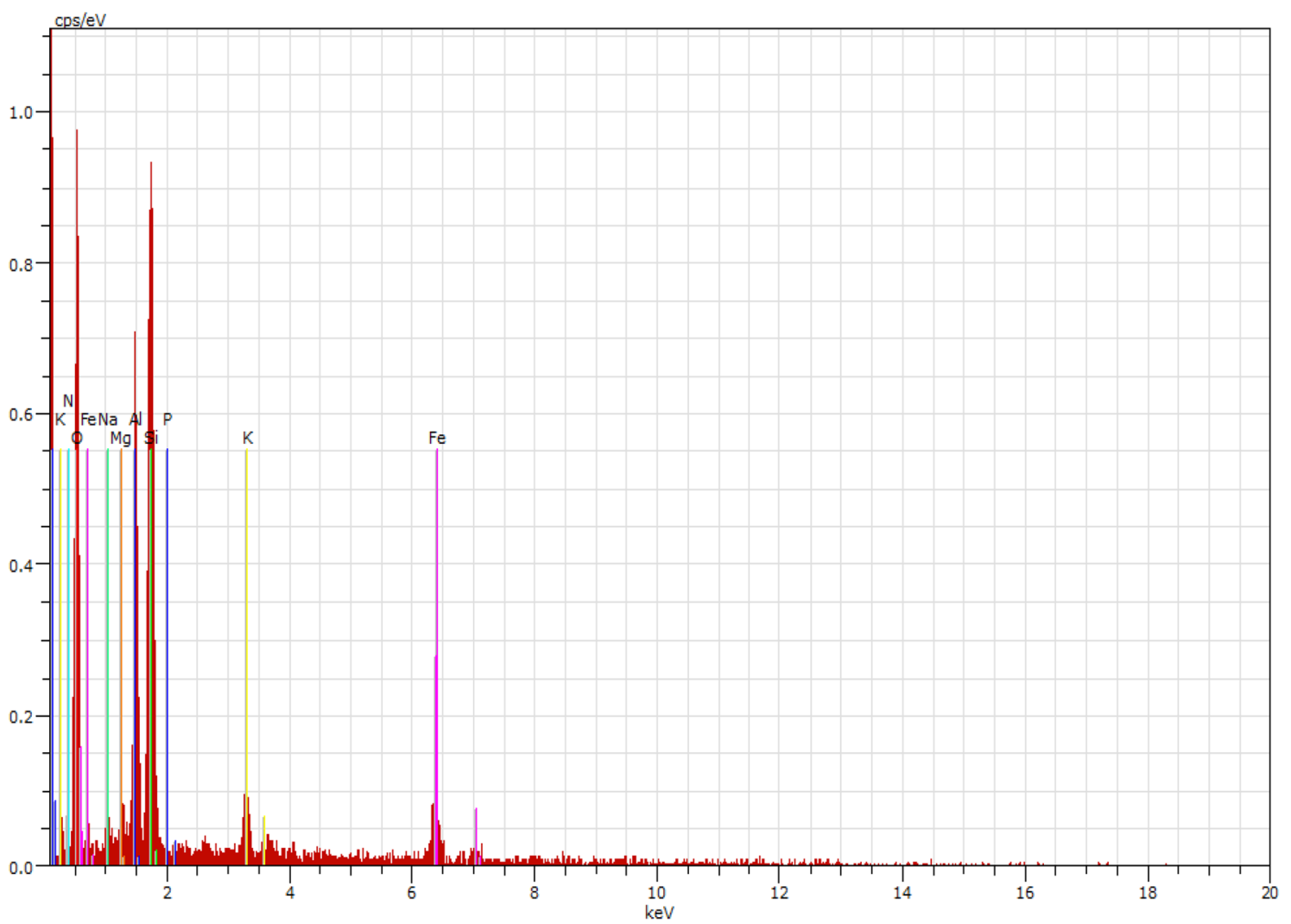

Fig. 5 EDS spectrum of RMS 


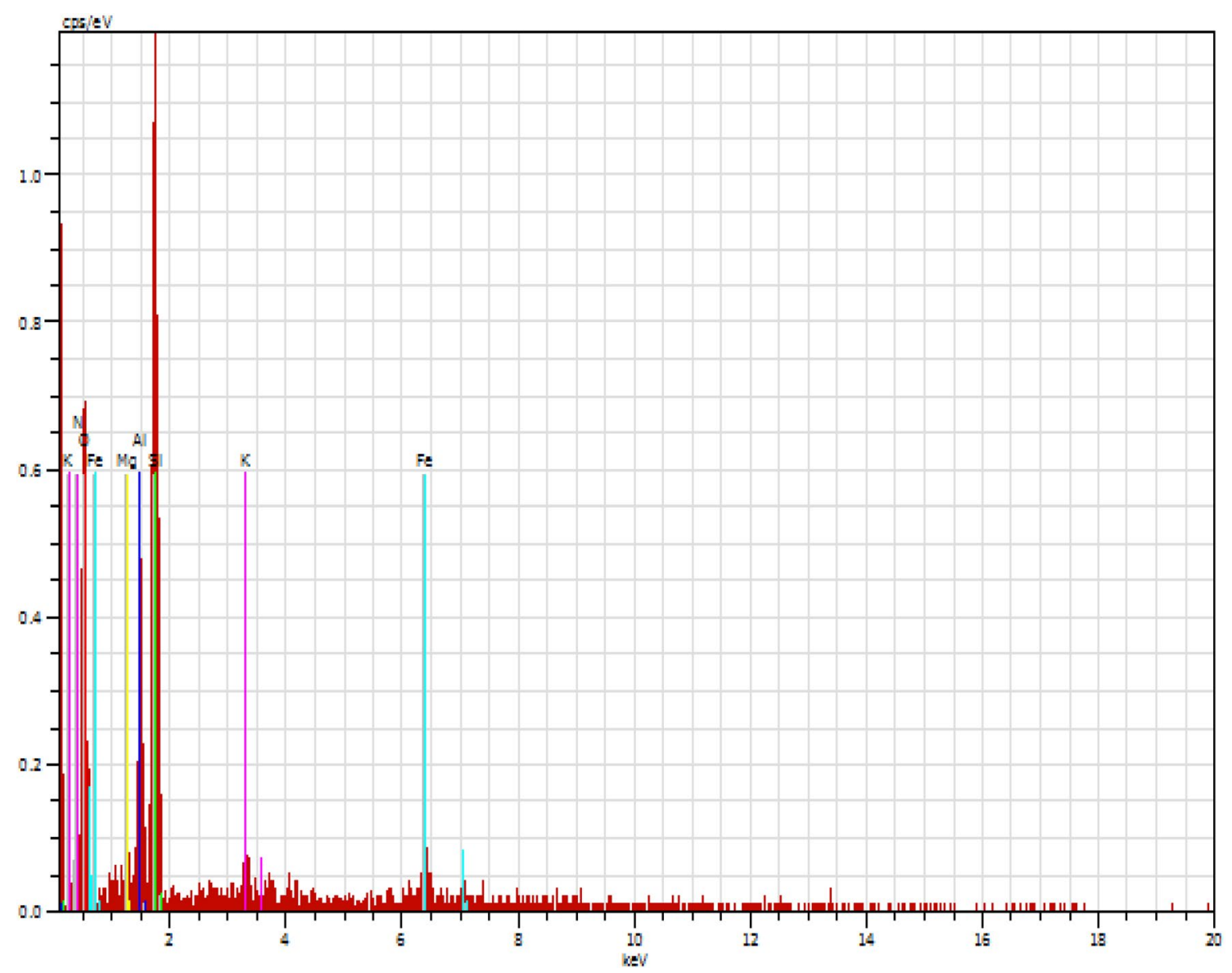

Fig. 6 EDS spectrum of WMS 


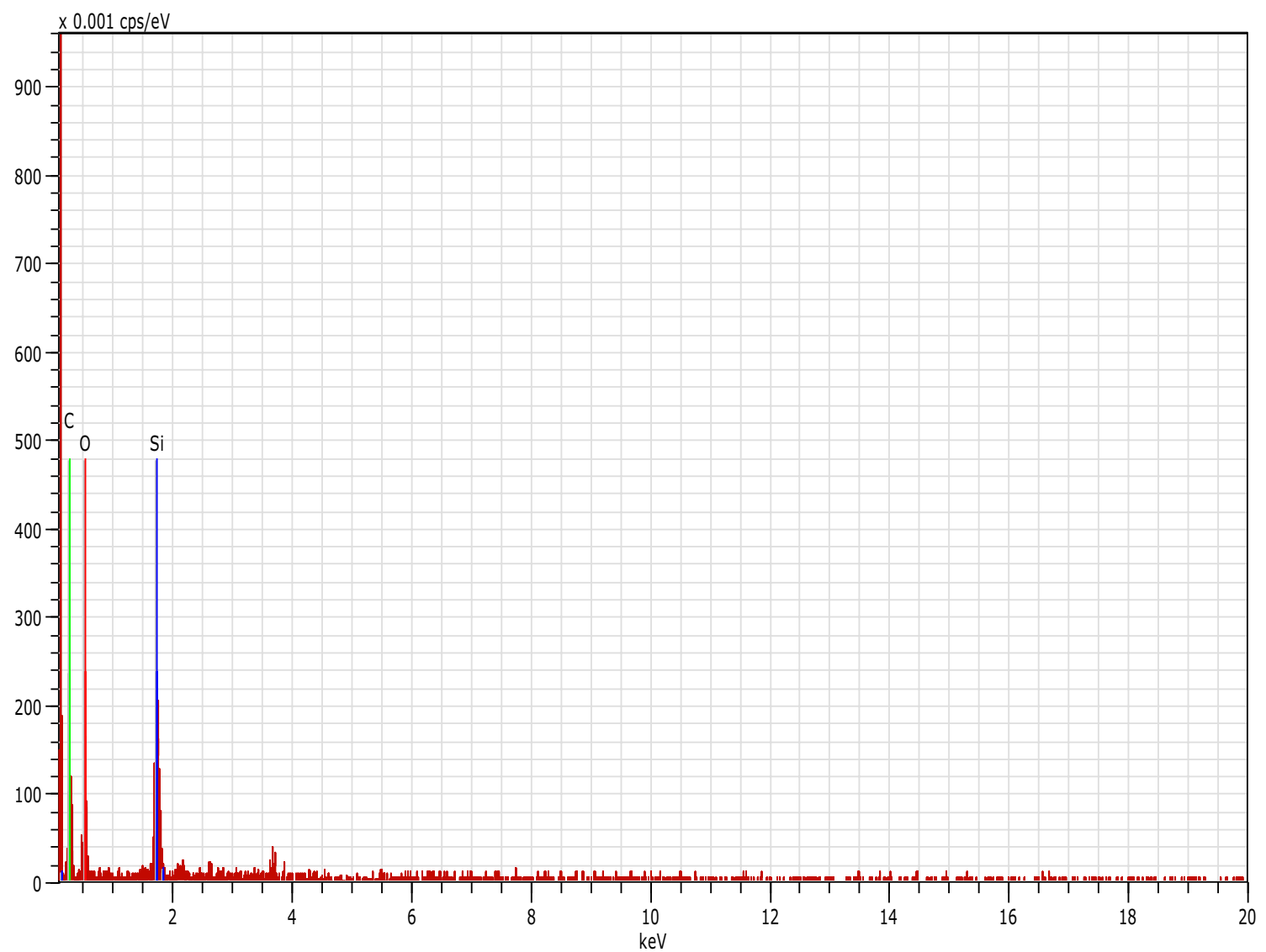

Fig. 7 EDS spectrum of RS 


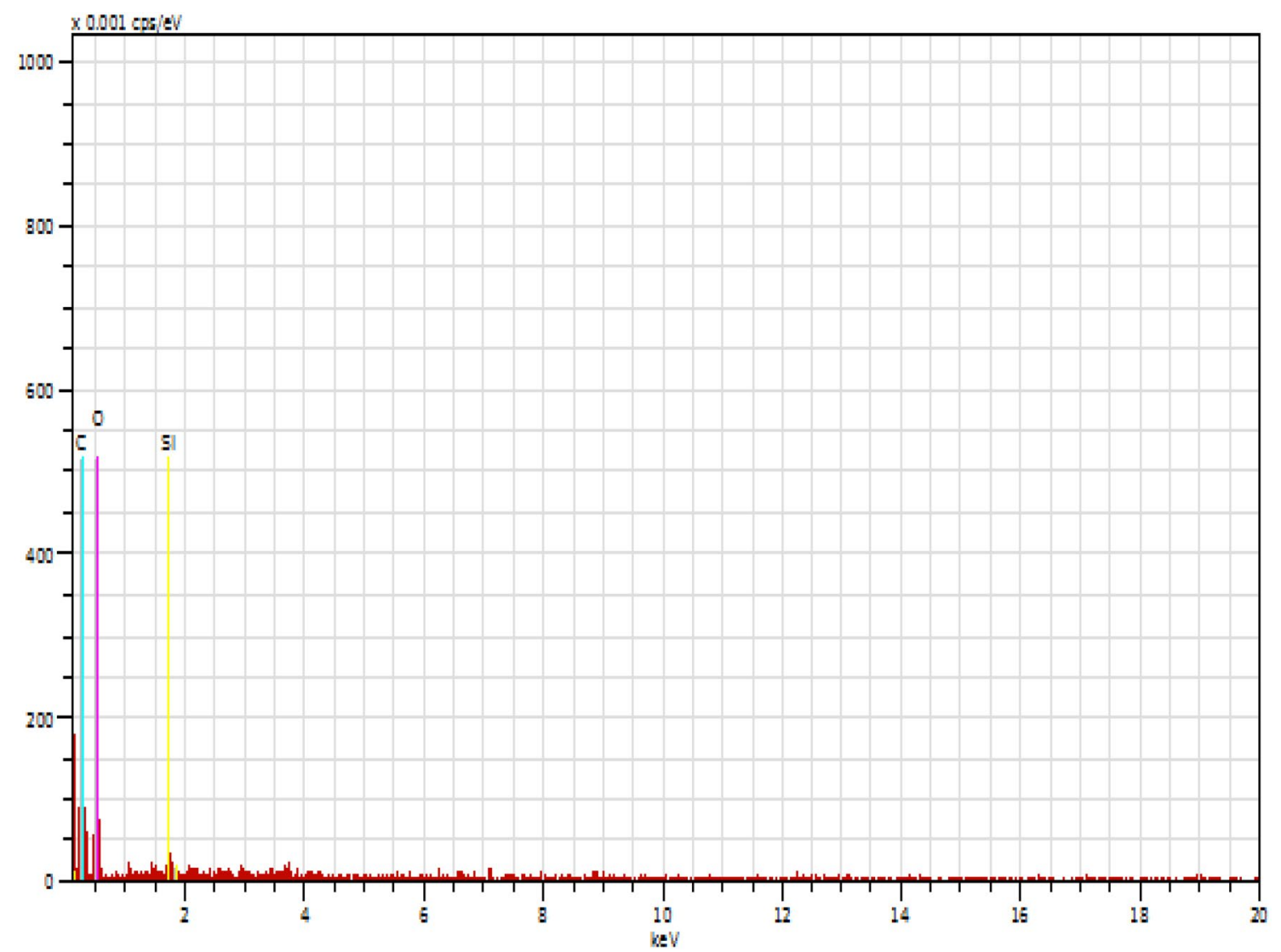

Fig. 8 EDS spectrum of WS

Open Access This article is distributed under the terms of the Creative Commons Attribution 4.0 International License (http://creativeco mmons.org/licenses/by/4.0/), which permits unrestricted use, distribution, and reproduction in any medium, provided you give appropriate credit to the original author(s) and the source, provide a link to the Creative Commons license, and indicate if changes were made.

\section{References}

Bhagat P, Gosal SK, Singh CB (2016) Effect of mulching on soil environment, microbial flora and growth of potato under field conditions. Indian J Agric Res 50(6):542-548. https://doi.org/10.18805 /ijare.v50i6.6671

Black AL (1973) Soil Property changes associated with crop residue management in a wheat-fallow rotation. Soil SciSocAm J 37(6):943-946. https://doi.org/10.2136/sssaj1973.0361599500 3700060039x

Burger MS, Nel PC (1984) Potato irrigation scheduling and straw mulching. S Afr J Plant Soil 1(4):111-116. https://doi. org/10.1080/02571862.1984.10634123

Chavan ML, Phad PR, Khodke UM, Jadhav SB (2010) Effect of organic mulches on soil moisture conservation and yield of rabi sorghum (M-35-1).Int J Agric Eng 2(2):322-328. http://www.researchjo urnal.co.in/online/IJAE/IJAE\%202(2)/2_A-322-328.pdf

Chen Y, Tarchitzky J, Brouwer J, Morin J, Banin A (1980) Scanning electron microscope observations on soil crusts and their formation. Soil Sci 130(1):49-55
CSKHPKV (2008) Package of Practices for Rabi Crops. http://www. hillagric.ac.in/extension/dee/pdf_files/Rabi_28-8-09.PDF

Dalrymple AW, Miller SD, Fornstone KJ (1993) Soil water conservation and winter wheat yield in three fallow systems. J Soil Water Conserv 48(1):53-57. http://www.jswconline.org/content/48/1/53. short

Dash SN, Pushpavathi Y, Behera S (2018) Effect of irrigation and mulching on growth, yield and water use efficiency of potato. Int J Curr Microbiol App Sci 7(2):2582-2587. https://doi.org/10.20546 /ijcmas.2018.702.314

Dechassa N, Schenk MK, Claassen N, Steingrobe B (2003) Phosphorus efficiency of cabbage (Brassica oleraceae L. var. capitata), Carrot (Daucus carota L.), and Potato (Solanum tuberosum L.). Plant Soil 250(2):215-224. https://doi.org/10.1023/A:1022804112388

Duiker SW, Lal R (1999) Crop residue and tillage effects on carbon sequestration in a Luvisol in central Ohio. Soil Till Res 52(12):73-81. https://doi.org/10.1016/S0167-1987(99)00059-8

Giordani C, Cecchi S, Zanchi C (2004) Effectiveness of different amounts of organic mulch on the conservation of soil moisture. $\mathrm{J}$ Agric Environ Int Dev 96(1/2):3-11

Havlin JL, Kissel DE, Maddus LD, Claassen MM, Long JH (1990) Crop rotation and tillage effects on soil organic carbon and nitrogen. Soil Sci Soc Am J 54(2):448-452. https://doi.org/10.2136/ sssaj1990.03615995005400020026x

Iwama K (2008) Physiology of the potato: new insights into root system and repercussions for crop management. Potato Res 51:333353. https://doi.org/10.1007/s11540-008-9120-3

Ji S, Unger PW (2001) Soil water accumulation under different precipitation, potential evaporation, and straw mulch conditions. 
Soil Sci Soc Am J 65(2):442-448. https://doi.org/10.2136/sssaj 2001.652442x

Kar G, Kumar A (2007) Effects of irrigation and straw mulch on water use and tuber yield of potato in eastern India. Agric Water Manag 94(1-3):109-116. https://doi.org/10.1016/j.agwat .2007.08.004

Kumar D, Singh R, Gadekar H, Patnaik US (2003) Effect of different mulches on moisture conservation and productivity of rainfed turmeric. Ind J Soil Conserv 31(1):41-44. http://agris.fao.org/agris -search/search.do?recordID=IN2005001091

Lesczynski DB, Tanner CB (1976) Seasonal variation of root distribution of irrigated, field-grown Russet Burbank potato. Am Potato J 53(2):69-78

Liu Y, Li Y, Li Q, Bao J, Hao D, Zhao Z, Hu Z (2015) Micro-to nanoscale morphologies and chemical components of soils investigated by SEM-EDS for forensic science. J Chem. https://doi. org/10.1155/2015/734560

Mahmood MM, Farooq K, Hussain A, Sher R (2002) Effect of mulching on growth and yield of potato crop. Asian J Plant Sci 1(2):132-133. https://doi.org/10.3923/ajps.2002.132.133

Mitchell JK (1993) Fundamentals of soil behaviour, 2nd edn. Wiley, New York, pp 131-160

MNRE (Ministry of New and Renewable Energy Resources) (2009) Govt. of India, New Delhi. www.mnre.gov.in/biomassrsources

Mulumba LN, Lal R (2008) Mulching effects on selected soil physical properties. Soil Till Res 98(1):106-111. https://doi.org/10.1016/j. still.2007.10.011

Opena GB, Porter GA (1999) Soil management and supplemental irrigation effects on potato: II. Root growth. Agron J 91:426-431. https://doi.org/10.2134/agronj1999.00021962009100030011x

Persson J, Kirchmann H (1994) Carbon and nitrogen in arable soils affected by supply of $\mathrm{N}$ fertilizers and organic manures. Agr Ecosyst Environ 51:249-255. https://doi.org/10.1016/01678809(94)90048-5

Poddar A, Kumar N, Shankar V (2018) Evaluation of two irrigation scheduling methodologies for potato (Solanum tuberosum L.) in north-western mid-hills of India. ISH J Hydraul Eng. https://doi. org/10.1080/09715010.2018.1518733

Powlson DS, Jenkinson DS (1981) A comparison of the organic matter, biomass, adenosine triphosphate and mineralizable nitrogen contents of ploughed and direct drilled soils. J Agr Sci 97:713-721. https://doi.org/10.1017/S0021859600037084

Rahman MA, Chikushi J, Saifizzaman M, Lauren JG (2005) Rice straw mulching and nitrogen response of no-till wheat following rice in Bangladesh. Field Crops Res 91(1):71-81. https://doi. org/10.1016/j.fcr.2004.06.010

Ramalan AA, Nwokeocha CU (2000) Effects of furrow irrigation methods, mulching and soil water suction on the growth, yield and water use efficiency of tomato in the Nigerian Savanna. Agric Water Manag 45(3):317-330. https://doi.org/10.1016/S0378 -3774(99)00104-3

Ramamurthy N, Kannan S (2009) SEM-EDS analysis of soil and plant (Calotropis gigantea Linn) collected from an Industrial village, Cuddalore Dt, Tamil Nadu, India. Rom J Biophys 19(3):219-226. https://www.rjb.ro/articles/252/nram.pdf

Rathore AL, Pal AR, Sahu KK (1998) Tillage and mulching effects on water use, root growth and yield of rainfed mustard and chickpea grown after lowland rice. J Sci Food Agr 78(2):149-161. https ://doi.org/10.1002/(SICI) 1097-0010(199810)78:2\%3c149:AIDJSFA94\%3e3.0.CO;2-U
Romero E, Simms PH (2008) Microstructure investigation in unsaturated soils: a review with special attention to contribution of mercury intrusion porosimetry and environmental scanning electron microscopy. Geotech Geoll Eng 26(6):705-727. https://doi. org/10.1007/s10706-008-9204-5

Saha UK, Hye MA, Haider J, Saha RR (1997) Effect of rice straw mulch on the water use and tuber yield of potato [Solanum tuberosum] grown under different irrigation schedules. Jpn J Trop Agr 41(3):168-176. https://doi.org/10.11248/jsta1957.41.168

Schnurer J, Larholm J, Rosswall T (1985) Microbial biomass and activity in an agricultural soil with different organic matter contents. Soil Biol Biochem 17:611-618. https://doi.org/10.1016/00380717(85)90036-7

Schonbeck MW, Evanylo GK (1998) Effects of mulches on soil properties and tomato production II. Plant-available nitrogen, organic matter input, and tilth-related properties. J Sustain Agr 13(1):83100. https://doi.org/10.1300/J064v13n01_07

Shankar V, Ojha CS, Govindaraju RS, Prasad KH, Adebayo AJ, Madramoottoo CA, Singh KK (2017) Optimal use of irrigation water. Sustain Water Resour Manag. https://doi.org/10.1061/97807 84414767.ch26

Shashidhar KR, Bhaskar RN, Priyadharshini P, Chandrakumar HL (2008) Effect of different organic mulches on $\mathrm{pH}$, organic carbon content and microbial status of soil and its influence on leaf yield of M5 mulberry (Morusindica L.) under rainfed condition. Current Biotica 2(4):405-413

Singh CP, Panigrahy S (2011) Characterisation of residue burning from agricultural system in India using space-based observations. J Indian Soc Remote 39(3):423. https://doi.org/10.1007/ s12524-011-0119-x

Stalham MA, Allen EJ, Rosenfeld AB, Herry FX (2007) Effects of soil compaction in potato (Solanum tuberosum) crops. J Agr Sci 145(4):295-312. https://doi.org/10.1017/S0021859607006867

Tariq JA, Khan MJ, Haq I (2001) Effect of mulching on root zone moisture content and yield of different sunflower varieties under rainfed conditions. J Eng Appl Sci 20(1):101-104. https://journ als.uetjournals.com/index.php/JEAS/article/view/2526

Teame G, Tsegay A, Abrha B (2017) Effect of organic mulching on soil moisture, yield, and yield contributing components of sesame (Sesamum indicum L.). Int J Agron 2017:1-6

Uniyal SP, Mishra AC (2003) Response of potato to soil moisture and temperature as affected by different mulches. J Indian Potato Assoc 30(3-4):315-317

Van Loon CD (1981) The effect of water stress on potato growth, development, and yield. Am Potato J 58:51-69. https://doi.org/10.1007/ BF02855380

Xing Z, Toner P, Chow L, Rees HW, Li S, Meng F (2012) Effects of Hay Mulch on Soil Properties and Potato Tuber Yield under Irrigation and Nonirrigation in New Brunswick, Canada. J Irrig Drain Eng 138(8):703-714. https://ascelibrary.org/doi/ full/10.1061/\%28ASCE\%29IR.1943-4774.0000459

Zhang XY, Chen SY, Dong P, Liu MY, Yong SH (2005) Evapotranspiration, yield and crop coefficient of irrigated maize under straw mulch. Pedosphere 15(5):576-584

Publisher's Note Springer Nature remains neutral with regard to jurisdictional claims in published maps and institutional affiliations. 